\title{
CXCL16-Mediated Cell Recruitment to Rheumatoid Arthritis Synovial Tissue and Murine Lymph Nodes Is Dependent Upon the MAPK Pathway
}

\author{
Jeffrey H. Ruth, ${ }^{1}$ Christian S. Haas, ${ }^{1}$ Christy C. Park ${ }^{2}$ M. Asif Amin, ${ }^{1}$ Rita J. Martinez, ${ }^{1}$ \\ G. Kenneth Haines, III, ${ }^{2}$ Shiva Shahrara, ${ }^{2}$ Phillip L. Campbell, ${ }^{1}$ and Alisa E. Koch ${ }^{3}$
}

Objective. Rheumatoid arthritis (RA) is characterized by profound mononuclear cell (MNC) recruitment into synovial tissue (ST), thought to be due in part to tumor necrosis factor $\alpha$ (TNF $\alpha$ ), a therapeutic target for RA. Although chemokines may also be involved, the mechanisms remain unclear. We undertook this study to examine the participation of CXCL16, a novel chemokine, in recruitment of MNCs to RA ST in vivo and to determine the signal transduction pathways mediating this process.

Methods. Using a human RA ST-SCID mouse chimera, immunohistochemistry, enzyme-linked immunosorbent assay, real-time reverse transcriptionpolymerase chain reaction, flow cytometry, and in vitro chemotaxis assays, we defined the expression and func-

Supported by the American Heart Association (grant 0425758Z), the Gallagher Professorship for Arthritis Research, the William D. Robinson and Frederick Huetwell Endowment, and funds from the Veterans Administration Research Service. Dr. Ruth's work was supported by the NIH (grant AR-049907), the Great Lakes Regional Center for AIDS Research, and the Michigan Chapter of the Arthritis Foundation. Dr. Koch's work was supported by the NIH (grants AI-40987, HL-58695, and AR-48267).

${ }^{1}$ Jeffrey H. Ruth, PhD, Christian S. Haas, MD, M. Asif Amin, MD, Rita J. Martinez, BS, Phillip L. Campbell, BS: University of Michigan Medical School, Ann Arbor, and Northwestern University Feinberg School of Medicine, Chicago, Illinois; ${ }^{2}$ Christy C. Park, MD, G. Kenneth Haines III, MD, Shiva Shahrara, PhD: Northwestern University Feinberg School of Medicine, Chicago, Illinois; ${ }^{3}$ Alisa E. Koch, MD: University of Michigan Medical School, Ann Arbor Northwestern University Feinberg School of Medicine, Chicago, Illinois, Veterans Administration Chicago Health Care Medical Center, Chicago, Illinois, and Ann Arbor Veterans Administration, Ann Arbor, Michigan.

Address correspondence and reprint requests to Alisa E. Koch, MD, University of Michigan Medical School, Department of Medicine, Rheumatology Division, 1150 West Medical Center Drive, Ann Arbor, MI 48109-0680. E-mail: aekoch@umich.edu.

Submitted for publication August 22, 2005; accepted in revised form December 1, 2005. tion of CXCL16 and its receptor, CXCR6, as well as the signal transduction pathways utilized by them for MNC homing in vitro and in vivo.

Results. CXCL16 was markedly elevated in RA synovial fluid (SF) samples, being as high as $145 \mathrm{ng} / \mathrm{ml}$. Intense macrophage and lining cell staining for CXCL16 in RA ST correlated with increased CXCL16 messenger RNA levels in RA ST compared with those in osteoarthritis and normal ST. By fluorescence-activated cell sorting analysis, one-half of RA SF monocytes and one-third of memory lymphocytes expressed CXCR6. In vivo recruitment of human MNCs to RA ST implanted in SCID mice occurred in response to intragraft injection of human CXCL16, a response similar to that induced by TNF $\alpha$. Lipofection of MNCs with antisense oligodeoxynucleotides for ERK-1/2 resulted in a $50 \%$ decline in recruitment to engrafted RA ST and a 5-fold decline in recruitment to regional lymph nodes. Interestingly, RA ST fibroblasts did not produce CXCL16 in response to TNF $\alpha$ in vitro, suggesting that CXCL16 protein may function in large part independently of TNF $\alpha$.

Conclusion. Taken together, these results point to a unique role for CXCL16 as a premier MNC recruiter in RA and suggest additional therapeutic possibilities, targeting CXCL16, its receptor, or its signaling pathways.

One of the earliest events in rheumatoid arthritis (RA) is the ingress of leukocytes into inflamed synovial tissue (ST). A number of cell-derived factors facilitate this process, including macrophage inflammatory protein $3 \alpha$ (MIP-3 $\alpha$ ), granulocyte-macrophage colonystimulating factor, monocyte chemoattractant protein 1 (MCP-1), MIP-1 $\alpha$, epithelial neutrophil-activating peptide 78 (ENA-78), fractalkine, and others (1-6). Thera- 
pies designed to block the activity or inhibit the production of these mediators and their corresponding receptors are currently being developed. Some chemokines function in a variety of ways, including initiating angiogenesis (6-8), binding of human immunodeficiency virus (HIV) surface proteins (9), and directly regulating immune responses to antigen (10). However, one of the primary functions of chemokines is their contribution to leukocyte homing (11).

Chemokines are redundant by nature, but they can be subdivided into inducible chemokines produced in response to inflammation and noninducible chemokines. The first group defines chemokines that recruit leukocytes, dendritic cells, and activated $\mathrm{T}$ cells to sites of inflammation. The second group defines the noninflammatory, constitutive chemokines expressed in bone marrow, thymus, and secondary lymphoid organs. Chemokines in the latter group are produced for normal physiologic leukocyte trafficking (12). However, regulation of leukocyte recruitment is complex and involves both secretion and cell surface presentation of chemokines, as well as their receptors, during leukocyte differentiation and activation (13). Thus, chemokines are produced in response to a variety of stimuli. For instance, in RA ST fibroblasts, interleukin- $1 \beta$ (IL-1 $\beta$ ) and tumor necrosis factor $\alpha(\mathrm{TNF} \alpha)$ are well-known stimuli (14-18).

Chemokines are further subdivided into so-called "CXC" $(\alpha)$ or "CC" $(\beta)$ chemokines. These designations are derived from the location of 2 adjacent aminoterminus cysteine residues. We and others have shown that many $\mathrm{CC}$ chemokines and their receptors, such as CCR5, a receptor for the CC chemokines MIP- $1 \alpha$ and RANTES, are up-regulated in the RA joint (19-21). The CXC chemokines are also active mediators of inflammation in the RA joint. Examples of this class of chemokines that are important in RA include IL-8 and ENA-78 $(6,14,22,23)$.

Much like fractalkine, CXCL16 has a chemokine domain without the proangiogenic "ELR" (glutamateleucine-arginine) motif $(4,24)$, and it is flanked by a typical mucin structure that is rich in serine, threonine, and proline. Both fractalkine and CXCL16 contain a hydrophobic transmembrane domain and a short cytoplasmic tail (24). Other similarities exist between CXCL16 and fractalkine, including the expression of a transmembrane domain suspended by a heavily glycosylated mucin stalk and the fact that both proteins exist as either membrane-associated or secreted forms. These chemokines contain a small cytoplasmic domain with a "YXPV" motif that is a potential tyrosine phosphoryla- tion and SH2-binding site, and is preferentially expressed by type 1 lymphocytes. Finally, CXCL16 has a unique receptor-ligand interaction, much like fractalkine (24-26). These characteristics are important, considering the proinflammatory functions of fractalkine in RA and in rat adjuvant-induced arthritis (AIA) $(3,4)$. Thus, the similar physical properties of fractalkine and CXCL16 are likely to result in similar proinflammatory activity.

CXCR6, the only known receptor for CXCL16, is also known as Bonzo, TYMSTR, and STRL33, and is a newly characterized chemokine receptor initially described as an HIV coreceptor expressed by a subset of memory/T effector cells, natural killer cells, and plasma cells (26-30). The present study directly addresses the participation of both CXCR6 and its ligand CXCL16 in leukocyte migration in RA. CXCR6-expressing leukocytes may also use this receptor to migrate into lymphocyte-rich regions such as lymph nodes (LNs). By expressing a receptor known to actively bind HIV, CXCR6+ lymphocytes may aid in the spread of viral infections (24). We show here that CXCL16 contributes to chronic inflammation, since it is highly expressed in RA synovial fluid (SF), is a potent chemoattractant for mononuclear cells (MNCs) in vitro, and is chemotactic for peripheral blood mononuclear cells (PBMCs) to RA ST and LNs in vivo.

\section{PATIENTS AND METHODS}

Patient samples. SF samples were obtained during arthrocentesis from patients with RA, osteoarthritis (OA), and other diseases including juvenile rheumatoid arthritis (JRA), psoriatic arthritis (PsA), polyarthritis, spondylarthropathy, inflammatory myopathy, and gout. Peripheral blood (PB) sera were also obtained from patients with arthritides (RA, OA, JRA, PsA, polyarthritis, and gout), and PB samples were obtained from healthy normal volunteers. STs were obtained from RA patients undergoing total joint replacement who met the American College of Rheumatology (formerly, the American Rheumatism Association) 1987 revised criteria for the classification of RA (31). Normal STs were obtained from fresh autopsies or from amputations. All specimens were obtained with Institutional Review Board approval.

SCID mice. SCID/NCr mice were purchased from the National Cancer Institute (Bethesda, MD). SCID mice were maintained in a pathogen-free animal facility and given food and water ad libitum.

Depletion of rheumatoid factor (RF) from sera and SF. To avoid any possible confounding effects of RF on assays, RF was immunodepleted from sera and SF samples using anti-IgM antibodies coupled to agarose beads (Sigma, St. Louis, MO) as previously described (3). Removal of RF (IgM) was determined by randomly choosing 5 RA SF samples and measuring RF levels before and after immunodepletion using 
an RF enzyme-linked immunosorbent assay (ELISA) kit (RDI, Flanders, NJ). Before immunodepletion, RF levels ranged from $5 \mathrm{IU} / \mathrm{ml}$ to $300 \mathrm{IU} / \mathrm{ml}$. After immunodepletion, all samples had RF levels below the detection limit of the assay $(0.031 \mathrm{IU} / \mathrm{ml}$; data not shown). Samples immunodepleted of RF were used in the ELISA and chemotaxis studies.

Sandwich ELISA. CXCL16 levels were measured by coating 96-well polystyrene plates with rabbit anti-human CXCL16 (PeproTech, Rocky Hill, NJ), followed by a blocking step as described previously (3). All samples were added in triplicate. Biotinylated rabbit anti-human antibody (PeproTech) was used to detect CXCL16 using a streptavidinperoxidase method (PharMingen, San Diego, CA), with a tetramethylbenzidine substrate (Sigma). Assay sensitivity was routinely $125 \mathrm{pg} / \mathrm{ml}$, and rabbit anti-human CXCL16 antibody demonstrated $<5 \%$ cross-reactivity with other recombinant human chemokines (data not shown).

Fluorescence-activated cell sorting (FACS) analysis. PB samples were obtained from normal volunteers and RA patients. SF cells were obtained from the joints of RA patients undergoing arthrocentesis. CXCR6 expression on CD14+ monocytes was evaluated by FACS analysis as previously described (11). Briefly, cells were incubated with fluorescein isothiocyanate (FITC)-labeled mouse anti-human CD14 (PharMingen) and mouse anti-human CXCR6 antibodies (CXCR6 IgG; kindly provided by Millennium Pharmaceuticals, Cambridge, MA). CXCR6 receptor expression was detected with R-phycoerythrin (R-PE)-labeled goat anti-mouse antibodies (Jackson ImmunoResearch, West Grove, PA). For some studies, CXCR6 receptor expression on lymphocyte subsets was evaluated by incubating cells with anti-CXCR6 antibodies or with energy-coupled dye-labeled anti-CD4 or anti-CD8 antibodies (Beckman Coulter, Miami, FL) with the addition of FITC-labeled (anti-CD45RA or anti-CD45RO) and Cy-Chrome-labeled (anti-CD3) antibodies (PharMingen) as previously described $(5,32)$.

Immunohistochemistry. We performed immunohistologic staining on cryosections from RA, OA, and normal STs using immunoperoxidase and avidin-biotin technique as described previously (3). Antibodies, including control antibodies, were used at $10 \mu \mathrm{g} / \mathrm{ml}$. Polyclonal rabbit anti-human CXCL16 antibodies (PeproTech) or monoclonal mouse antiCXCR6 antibodies were used as specific antibodies, and tissues were counterstained with Harris' hematoxylin. STs were also stained with the appropriate IgG control antibodies for comparison (CXCL16 control antibody was rabbit IgG and was obtained from R\&D Systems [Minneapolis, MN]; CXCR6 control antibody was mouse $\operatorname{IgG} 2 \alpha$ and was obtained from Beckman Coulter). For some immunohistologic experiments, STs were stained with mouse anti-human CXCR6 from a different vendor to check for staining consistency (mouse anti-human CXCR6 was obtained from R\&D Systems; control mouse $\operatorname{IgG} 2 \beta \kappa$ antibody was obtained from Beckman Coulter). Various ST cell types were evaluated for staining, including macrophages, lymphocytes, fibroblasts, and endothelial cells. Immunostaining was evaluated in a blinded manner and graded by a pathologist as described previously (33).

For 2-color immunofluorescence histology, serial ST sections $(8 \mu \mathrm{m})$ were cut, allowed to dry for 2 hours at room temperature, and subsequently fixed in acetone for 10 minutes at $4^{\circ} \mathrm{C}$. Following a wash with phosphate buffered saline (PBS), sections were blocked with $3 \%$ fetal bovine serum (FBS)/PBS for 30 minutes at $37^{\circ} \mathrm{C}$. Either mouse anti-human CXCR6 antibodies or goat anti-human CXCL16 antibodies (final concentration $10 \mu \mathrm{g} / \mathrm{ml}$; both from R\&D Systems) were added as primary antibodies and incubated for 2 hours at room temperature. Mouse or goat $\mathrm{IgG}$ served as controls. After washing twice with PBS, Alexa 488-labeled donkey anti-mouse or anti-goat antibody was added and incubated at room temperature for 1 hour. PE-tagged rat anti-human CD14 antibody (diluted 1:200 in PBS; Ancell, Bayport, MN) was used to detect CD14+ macrophages. After washing with PBS, nuclei were counterstained with 4',6-diamidino-2-phenylindole (Molecular Probes, Eugene, OR) and coverslipped. Serial sections were examined with a BX51 Fluorescence Microscope System using DP Manager imaging software (Olympus America, Melville, NY). Photographs were merged, and CXCL16 (red)- and/or CXCR6 (red)-expressing CD14+ macrophages (green) were identified by yellow fluorescence microscopy.

Real-time reverse transcription-polymerase chain reaction (RT-PCR) (TaqMan). Total RNA was extracted from joints by the procedure of Chomczynski and Sacchi (34). The final RNA was digested with DNase and with an RNase inhibitor added. Reverse transcription was performed simultaneously using Superscript II reverse transcriptase (Invitrogen, Carlsbad, CA) followed by the PCR reactions and preparation of serial dilutions of the purified PCR products (35). PCR primers and TaqMan fluorogenic probes were designed using the Primer Express program, version 1.01 (Applied Biosystems, Foster City, CA). For human CXCL16, the following primers and probe sequences were designed and used: $5^{\prime}$ primer, AAGCCATTGAGACACCAGCTG; 3' primer, ACCTCGCTCTGACTCCCAGA; and the probe, ACGTCACGCGCCGGAGCA. TaqMan probes carry a 5'-FAM reporter dye and a 3'-TAMRA quencher dye (Mega Bases, Evanston, IL). The quantity of complementary DNA (cDNA) of the gene of interest is directly related to the fluorescence detection of FAM. The amount of cDNA was calculated using a comparative cycle threshold method and the standard curve method according to Perkin Elmer ABI Prism 7700 User Bulletin no. 2, 1997 (36). The estimated amount of the gene of interest was normalized to the amount of GAPDH.

Isolation of human MNCs and chemotaxis. PB $(\sim 100$ $\mathrm{ml}$ ) was collected from normal healthy adult volunteers to obtain MNCs, and chemotaxis was performed as previously outlined (3) using 48-well chemotaxis chambers (Neuroprobe, Cabin John, MD) with a 5-mm polyvinylpyrrolidone-free polycarbonate filter (Poretics, Livermore, CA). Results were expressed as the number of MNCs migrating per high-power field (hpf). For CXCL16 neutralization studies, SF samples were preincubated either with goat anti-human CXCL16 IgG antibody or with an equivalent amount of a corresponding control antibody (nonspecific goat IgG; Beckman Coulter) for 1 hour at $37^{\circ} \mathrm{C}$. Neutralized SF samples were assayed for chemotactic activity for normal PBMCs. All chemotaxis assays included Hanks' balanced salt solution (HBSS) as the negative control and fMLP as the positive control.

RA ST fibroblast isolation and culture. ST fibroblasts isolated from patients with RA were cultured in 24-well plates (Becton Dickinson, Franklin Lakes, NJ) at 100,000/ml for 24 or 48 hours at $37^{\circ} \mathrm{C}$ in a $5 \% \mathrm{CO}_{2}$ atmosphere. RA ST fibroblasts were grown in RPMI medium (Invitrogen, Carlsbad, CA) 
supplemented with $10 \% \mathrm{FBS} / 1 \%$ penicillin-streptomycin. For some cultures, fibroblasts were grown in media containing either TNF $\alpha$ (30 ng/ml; Pfizer, Kalamazoo, MI) or IL-1 $\beta$ (30 $\mathrm{ng} / \mathrm{ml}$; Pfizer). Supernatants were assayed for CXCL16 and control chemokines.

Cell culture, cell lysis, immunoblotting, and immunoprecipitation. Cell lysis and immunoblotting were performed as described previously $(37,38)$. Briefly, freshly isolated human MNCs were incubated in 6-well plates for at least 12 hours $\left(2 \times 10^{6} /\right.$ well $)$ in serum-free RPMI 1640 prior to stimulation with $10 \mathrm{n} M$ CXCL16 for various time periods. Immunoprecipitation was performed according to the protocol of Roche (Basel, Switzerland). Protein A-agarose or protein G-agarose (Roche) was washed twice with $1 \mathrm{ml}$ of lysis buffer. MNC lysate $(400 \mu \mathrm{g})$ was added to the washed protein A-agarose or protein $\mathrm{G}$-agarose for 1 hour at $4^{\circ} \mathrm{C}$. After centrifugation, supernatant was incubated with $7 \mu$ l of antiphosphotyrosine antibody (Cell Signaling Technology, Beverly, MA) and $50 \mu \mathrm{l}$ of protein A-agarose or protein $\mathrm{G}$-agarose overnight at $4^{\circ} \mathrm{C}$. Suspensions were washed twice with lysis buffer. Thereafter, pellets were resuspended in $2 \times$ Laemmli sample buffer and boiled for 3 minutes. Supernatants were used in Western blot analysis.

Sodium dodecyl sulfate-polyacrylamide gel electrophoresis (SDS-PAGE) and Western blotting. Protein lysate $(15-20 \mu \mathrm{g})$ was run on SDS-PAGE gels and transblotted to nitrocellulose membranes using a semidry transblotting apparatus (Bio-Rad, Hercules, CA). Nitrocellulose membranes were blocked with $5 \%$ nonfat milk in Tris buffered salineTween 20 (TBST) for 60 minutes at room temperature. Blots were incubated overnight at $4^{\circ} \mathrm{C}$ with optimally diluted specific primary antibody in TBST containing 5\% nonfat milk. Phosphorylation state-specific antibodies to ERK-1/2 (Cell Signaling Technology), Src (BioSource International, Camarillo, CA), and Raf-1 (BioSource International) were used as primary antibodies. Blots were washed 3 times and incubated in horseradish peroxidase-conjugated antibody (1:10,000 dilutions) for 1 hour at room temperature. Protein bands were detected using enhanced chemiluminescence (GE Healthcare, Piscataway, NJ) in accordance with the manufacturer's instructions. Blots were scanned and analyzed for band intensities using UN-SCAN-ITJ version 5.1 software (Silk Scientific, Orem, UT)

Generating human ST-SCID mouse chimeras. To generate chimeras, we obtained human ST from RA patients undergoing joint replacement. SCID/NCr mice (6-8 weeks old), having a B lymphocyte and $\mathrm{T}$ lymphocyte defect, were anesthetized, and graft beds were prepared subcutaneously in the backs (behind the left ear) of mice. One RA ST specimen $(\sim 1 \times 1 \times 0.05 \mathrm{~cm})$ was implanted per animal, and the wound was gently sutured. Grafts were allowed to "take" and were used 4-6 weeks after transplantation. Only those animals without gross evidence of inflammation or rejection were used.

After engraftment, freshly isolated human MNCs were dye-tagged with PKH26 fluorescent dye (Sigma, St. Louis, MO). Cytospins were prepared to determine successful labeling of cells using a fluorescence microscope with a $550-\mathrm{nm}$ filter. Labeled cells $\left(5 \times 10^{6}\right)$ were injected intravenously (IV) via the tail vein, and 48 hours later, animals were killed and grafts and LNs were removed and snap-frozen in liquid nitrogen. Cryosections (10- $\mu \mathrm{m}$ thick) were examined in a blinded manner for cell homing using a fluorescence microscope at $550 \mathrm{~nm}$. Migrating fluorescent MNCs were quantified in grafts and LNs by counting the total number of cells per hpf in at least 3 sections per tissue. To examine homing of MNCs in response to chemotactic stimuli, we injected $1 \mu \mathrm{g}$ recombinant human CXCL16 or $200 \mathrm{ng}$ TNF $\alpha$ directly into implanted grafts prior to IV injection of labeled cells. This is done by gently palpating the mouse around the scruff of the neck for engrafted RA ST and carefully injecting the needle directly into the grafts. The concentrations of intragraft-injected cytokines were those previously shown to be effective in vivo (39). Control chimeras received labeled cells but no stimulus.

Transient transfection of human MNCs. Isolated human PBMCs were plated overnight in 6-well plates with serum-free RPMI 1640 medium and subsequently transfected using Lipofectin reagent (Invitrogen). Oligodeoxynucleotide (ODN) DNA $(10 \mu M)$ and Lipofectin $(5 \mu \mathrm{l})$ were incubated separately in $100 \mu \mathrm{l}$ of serum-free medium for 30 minutes. Solutions were mixed gently, and $880 \mu \mathrm{l}$ of medium was added. A DNA-Lipofectin mixture was added to the preincubated MNCs with an additional incubation of at least 5 hours before use for the in vitro and in vivo signaling studies. For transient transfection of human MNCs, the following sense and antisense ODNs were used with subsequent CXCL16 stimulation for in vivo migration assays: ERK-1/2 sense, $5^{\prime}$ ATGGCGGCGGCGGCGGC-3' and ERK-1/2 antisense, 5' $^{\prime}$ GCCGCCGCCGCCGCCAT-3'. Transfection of ODNs peaked at 5 hours, with an efficiency routinely $>80 \%$.

Once transfected, MNCs were labeled with PKH26 dye, washed, and injected IV into RA ST-engrafted SCID mice at a concentration of $5 \times 10^{6} / 100 \mu \mathrm{l} /$ mouse. We performed viability counts on cells transfected with sense and antisense ODNs for several signaling molecules, including ERK-1/2 (cell viability $82 \%$ sense, $92 \%$ antisense), Src (cell viability $98 \%$ sense, $97 \%$ antisense), and phosphatidylinositol 3-kinase (PI 3-kinase) (cell viability 97\% sense, $100 \%$ antisense). Cell viabilities were evaluated with at least 100 cells counted per group. As described above, some mice received simultaneous intragraft injections of CXCL16 $(1 \mu \mathrm{g} / 100 \mu \mathrm{l}$ per mouse) when dye-tagged cells were administered IV.

Statistical analysis. Statistical analysis was done by Student's $t$-test. $P$ values less than 0.05 were considered significant.

\section{RESULTS}

Up-regulation of CXCR6 expression in CD14+ monocytes and memory lymphocytes in RA SF. Normal or RA PB monocytes expressed virtually no CXCR6, while $50 \%$ of RA SF monocytes expressed this receptor (Figure 1A). This suggests that monocytes in RA SF might be a target for CXCL16. While only a small minority of normal or RA PB CD3+ lymphocytes expressed CXCR6, a mean of $33 \%$ of RA SF CD3+ lymphocytes expressed this receptor, as determined by 4-color flow cytometry (Figure 1B). Similar results were obtained for $\mathrm{CD} 3+, \mathrm{CD} 8+, \mathrm{CD} 45 \mathrm{RO}+, \mathrm{CXCR} 6+$ lym- 
A
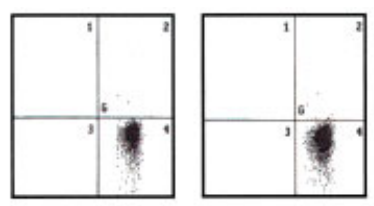

NL PB

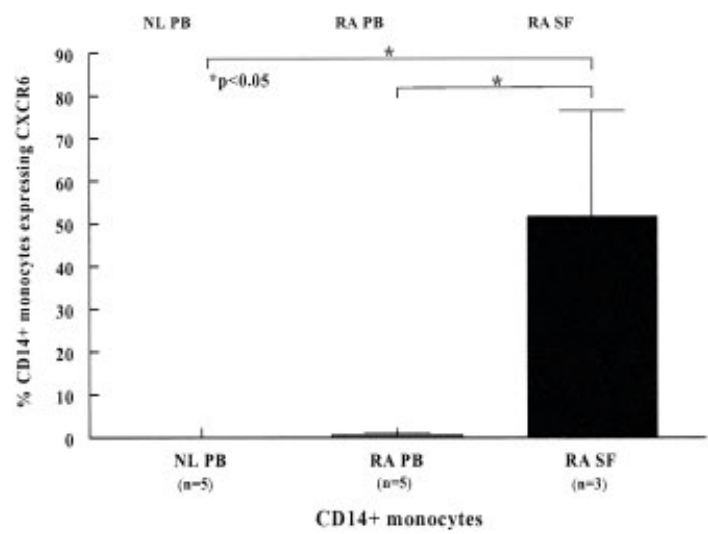

B
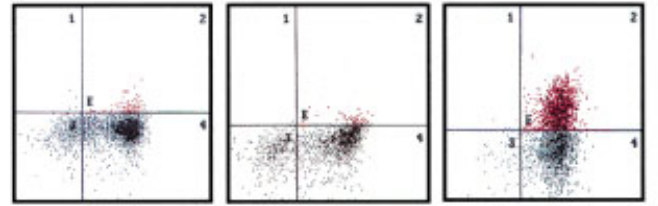

NL. PB

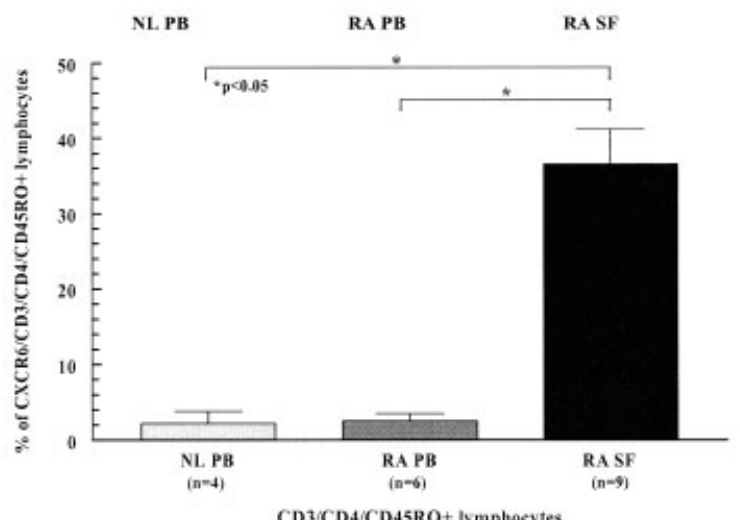

C

D
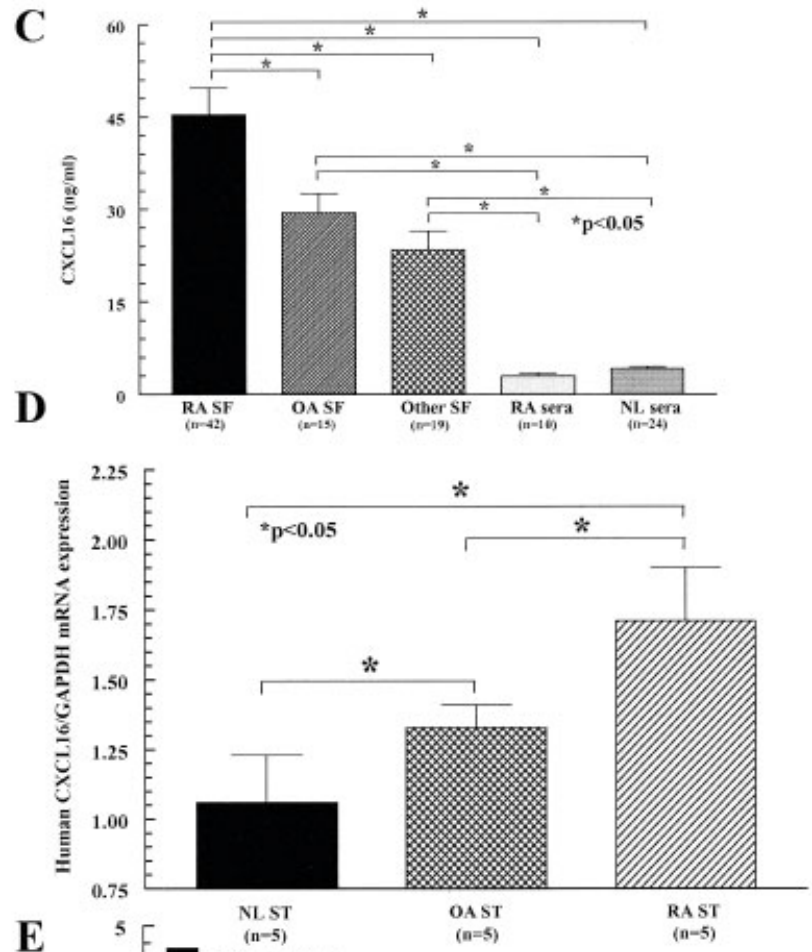

E

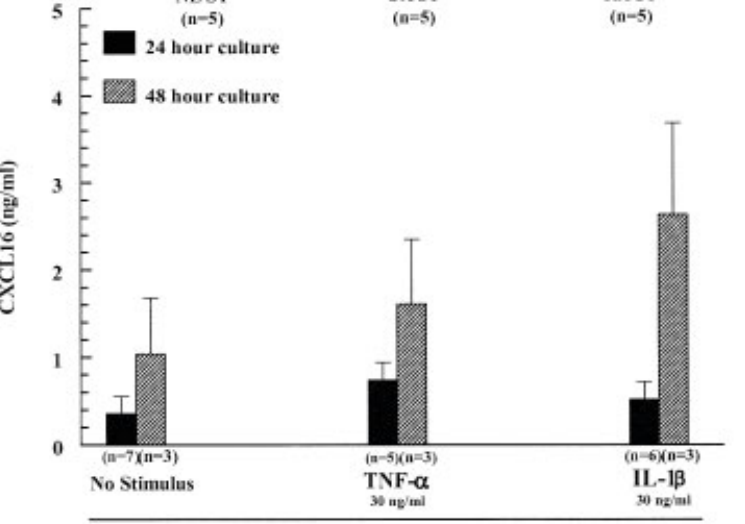

RA fibroblast culture supernatants

Figure 1. Flow cytometric analysis identifying the percentage of CD14+ monocytes expressing CXCR6 (red cells in dot plots) in normal (NL) peripheral blood (PB), PB from patients with rheumatoid arthritis (RA), and synovial fluid (SF) from RA patients. A, Representative dot plot of CD14+ monocyte CXCR6 expression with corresponding graph of results. CD14+ monocytes did not significantly express CXCR6 in normal or RA PB. However, $\sim 50 \%$ of CD14+ monocytes from RA SF expressed CXCR6. B, Four-color fluorescence-activated cell sorting analysis on memory lymphocytes (with corresponding graph of results) identifying elevated percentages of memory CD3+,CD4+,CD45RO+,CXCR6+ lymphocytes in RA SF compared with normal and RA PB. Similar results were obtained for memory CD3+,CD8+,CD45RO+,CXCR6+ lymphocytes (data not shown). C, CXCL16 concentrations in RA SF were significantly elevated compared with those in normal PB, RA PB, SF from patients with osteoarthritis (OA), and other SF samples. D, Normal, OA, and RA synovial tissue (ST) CXCL16 mRNA expression was also evaluated by real-time reverse transcription-polymerase chain reaction. RA ST had elevated expression of CXCL16 mRNA, indicating that factors in the RA joint support CXCL16 expression at the level of transcription. E, Fibroblasts are one source of CXCL16 in RA. RA fibroblasts produced CXCL16 after culture for 24 or 48 hours and did not respond significantly to exogenous cytokine (tumor necrosis factor $\alpha$ [TNF $\alpha$ ] or interleukin- $1 \beta$ [IL- $1 \beta]$ ) stimulation at either time point. Values are the mean and SEM ( $\mathrm{n}=$ number of patient samples). Color figure can be viewed in the online issue, which is available at http://www.arthritisrheum.org. 

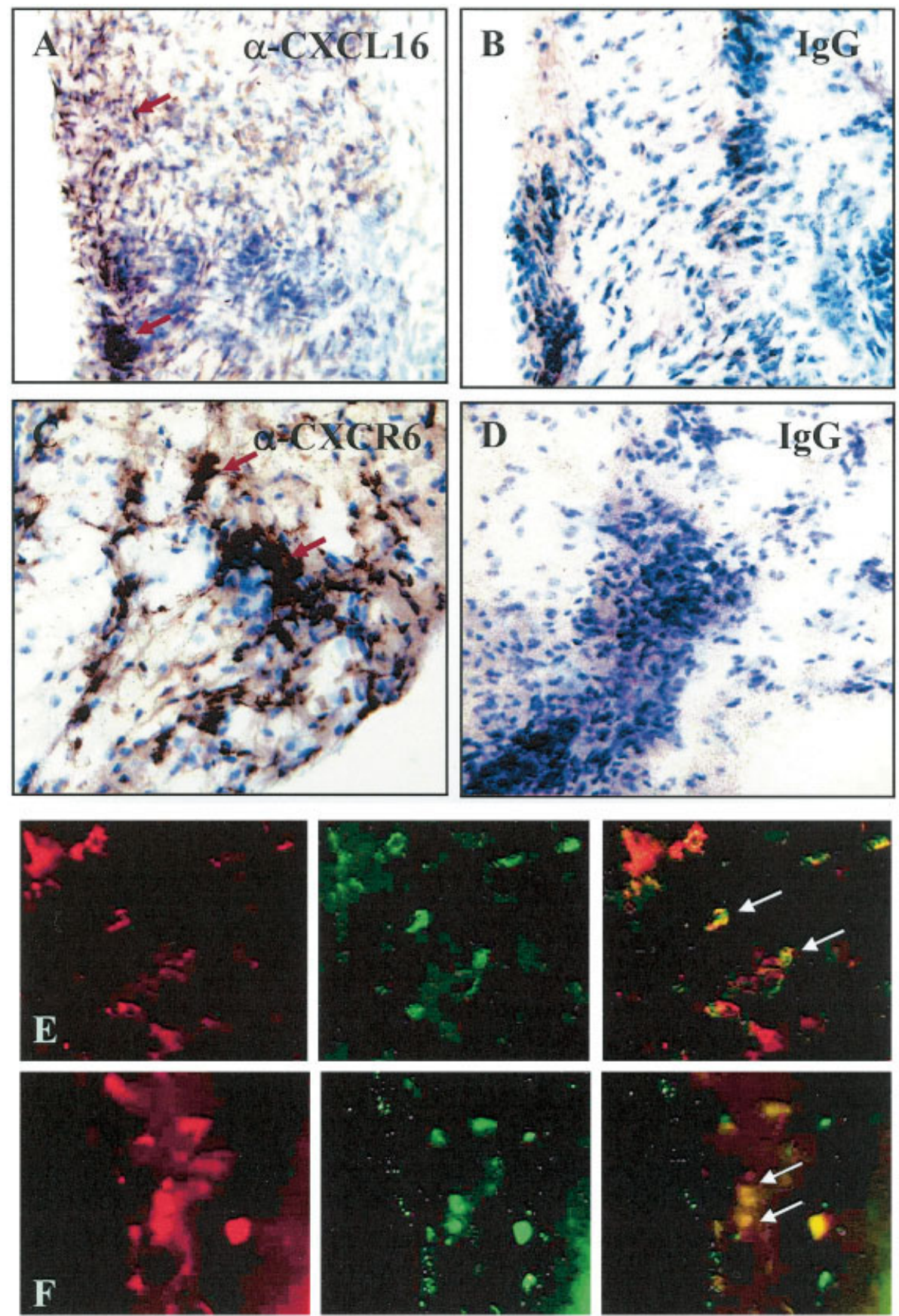

Figure 2. A and C, Immunostaining of RA ST for CXCL16 and CXCR6, respectively. B and D, Staining with the IgG control antibody. Macrophages stained positive for both CXCL16 and CXCR6 in RA ST (arrows in A and C). E and F, Phycoerythrin-tagged rat anti-human CD14 antibody was added to detect CD14+ macrophages. Photographs were merged, and CXCL16-expressing (red in E) and/or CXCR6-expressing (red in F) CD14+ macrophages (green) were identified by yellow fluorescence microscopy (arrows). RA ST CD14+ macrophages expressed both CXCL16 and CXCR6. Table 1 summarizes the various cell types staining positive for CXCL16 and CXCR6 in RA, OA, and normal ST. $\alpha$-CXCL16 $=$ antibody to CXCL16; $\alpha$-CXCR6 = antibody to CXCR6 (see Figure 1 for other definitions). (Original magnification $\times 200$ in $\mathbf{A}-\mathbf{D} ; \times 400$ in $\mathbf{E}$ and $\mathbf{F}$.)

phocytes (data not shown). This indicates that CXCR6 receptor expression is on both monocytes and T lymphocytes in the RA joint.
Elevated CXCL16 concentration in RA. We found that the CXCL16 concentration in RA SF was significantly elevated compared with that in $\mathrm{OA}$ and 
Table 1. Summary of immunostaining shown in Figure 2*

\begin{tabular}{llllll}
\hline & \multicolumn{2}{c}{ CXCL16+ cells, \% } & & \multicolumn{2}{c}{ CXCR6+ cells, \% } \\
\cline { 2 - 3 } \cline { 5 - 6 } \cline { 5 - 6 } & Lining cells & Macrophages & & Lining cells & Macrophages \\
\hline Normal ST $\dagger$ & $29.9 \pm 8.2$ & $64.3 \pm 6.2$ & & $9.4 \pm 2.7$ & $41.7 \pm 4.9$ \\
OA ST $\dagger$ & $20.6 \pm 7.2$ & $41.0 \pm 8.6 \ddagger$ & & $7.2 \pm 2.9$ & $49.6 \pm 4.5$ \\
RA ST $\dagger$ & $78.3 \pm 6.9 \S$ & $77.5 \pm 3.0$ & & $38.1 \pm 6.6 \S$ & $72.6 \pm 4.6 \S$ \\
\hline
\end{tabular}

$*$ Values are the mean \pm SEM. $\mathrm{ST}=$ synovial tissue; $\mathrm{OA}=$ osteoarthritis; RA = rheumatoid arthritis.

$\dagger$ CXCL16+ cells were obtained from 4 healthy normal volunteers, 5 OA patients, and 4 RA patients. CXCR6+ cells were obtained from 5 healthy normal volunteers, 5 OA patients, and 7 RA patients.

$\ddagger P<0.05$ versus normal and RA ST.

$\S P<0.05$ versus normal and OA ST.

other SF samples $(P<0.05)$ and 8 times greater than that in sera from normal healthy people (Figure 1C). These results point toward a significant function of CXCL16 in the inflammatory environment of the RA joint.

We also measured CXCL16 messenger RNA (mRNA) expression in RA ST by real-time RT-PCR. Normal ST as well as ST obtained from patients with OA and RA was snap-frozen and prepared for mRNA analysis. Samples were reverse-transcribed into cDNA and examined for CXCL16 mRNA by real-time RTPCR. RA ST contained elevated levels of CXCL16 mRNA compared with normal and OA ST, confirming that CXCL16 was up-regulated in RA joint inflammation (Figure 1D). We identified one source of CXCL16 expression by culturing RA fibroblasts for 48 hours with and without cytokine stimulation. Figure $1 \mathrm{E}$ shows that unstimulated RA fibroblasts produced significant amounts of CXCL16 (up to $0.5 \mathrm{ng} / \mathrm{ml}$ at 24 hours and 1 $\mathrm{ng} / \mathrm{ml}$ at 48 hours), which were not significantly upregulated with the addition of TNF $\alpha$ or IL- $1 \beta$. This is contrary to our previous findings with fractalkine and MIP- $3 \alpha$, since we showed that RA ST fibroblasts could be stimulated to produce significantly elevated levels of these chemokines when stimulated with $\mathrm{TNF} \alpha$ (fractalkine and MIP-3 $\alpha$ ) or IL- $1 \beta$ (MIP-3 $\alpha)(3,5)$.

Expression of CXCL16 and CXCR6 in RA ST by immunohistology. As shown in Figure 2, CXCL16 and CXCR6 were immunolocalized in ST obtained from patients with active RA. Figure 2A shows representative immunostaining for CXCL16 in macrophages, while this was not observed in RA ST stained with the IgG control antibody (Figure 2B). Figure 2C shows RA ST stained with antibody to CXCR6. CXCL16 and CXCR6 were also immunolocalized primarily on macrophages in RA ST, while RA ST stained with control IgG antibody did not show significant reactivity (Figure 2D).

For 2-color immunofluorescence histology, serial ST sections were cut and stained either with mouse anti-human CXCR6 antibody or with goat anti-human CXCL16. Alexa 488-labeled donkey anti-mouse or donkey anti-goat antibody was also added as described in Patients and Methods. PE-tagged rat anti-human CD14 antibody was added to detect CD14+ macrophages. Photographs were merged, and CXCL16 (red)- and/or CXCR6 (red)-expressing CD14+ macrophages (green) were identified by yellow fluorescence microscopy (Figures $2 \mathrm{E}$ and F, respectively). As shown, RA ST CD14+ macrophages expressed both CXCL16 and CXCR6.

Table 1 summarizes the immunostaining shown in Figure 2. Although CXCL16 and CXCR6 were expressed in normal, OA, and RA ST, we observed significantly elevated macrophage staining for CXCL16

$\mathbf{A}$
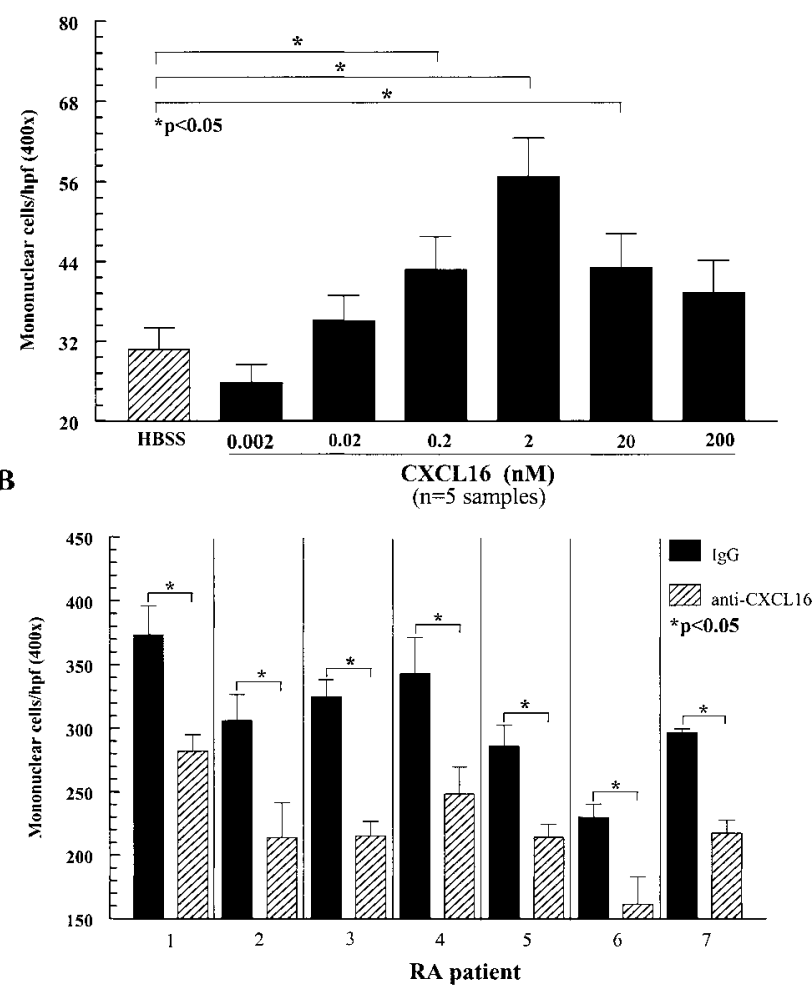

Figure 3. A, CXCL16 induces chemotaxis of human mononuclear cells in a dose-dependent manner and is maximal between concentrations of $2 \mathrm{n} M$ and $20 \mathrm{n} M$. B, Mononuclear cell migration was also measured in vitro in a chemotaxis assay using RA SF as a chemotactic agent after incubation with a neutralizing anti-CXCL16 antibody. Goat IgG served as a negative control (sham depletion). CXCL16 depletion resulted in an $\sim 30 \%$ reduction in RA SF-induced mononuclear cell migration. Note the similar reductions in mononuclear cell chemotaxis in every sample tested. Values are the mean and SEM $(\mathrm{n}=$ number of cell isolations from different blood donors). $\mathrm{hpf}=$ high-power field; HBSS = Hanks' balanced salt solution (see Figure 1 for other definitions). 


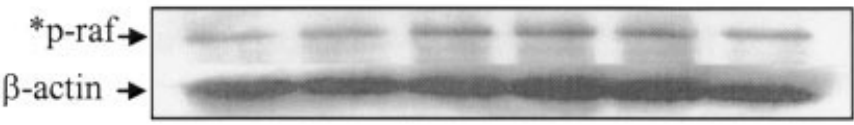

A

$\begin{array}{llllllll}0 \mathrm{~m} & 1 \mathrm{~m} & 5 \mathrm{~m} & 15 \mathrm{~m} & 30 \mathrm{~m} & 45 \mathrm{~m}\end{array}$

B

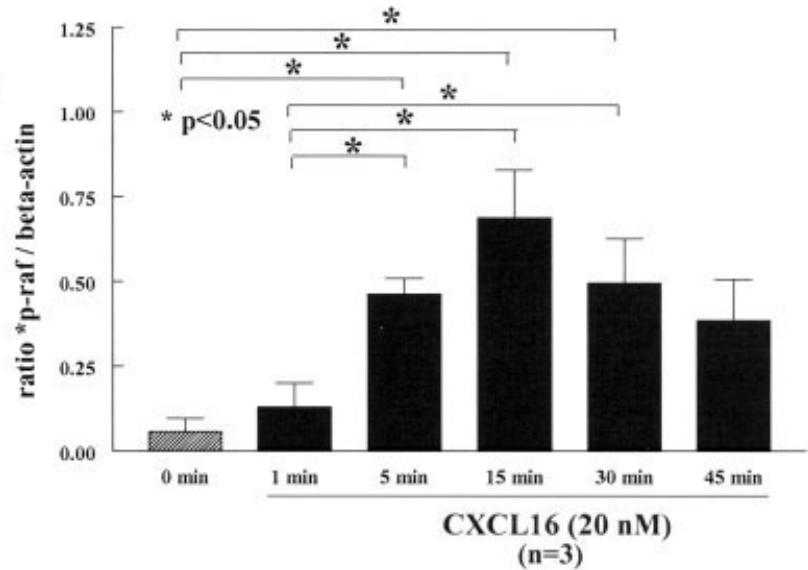

C

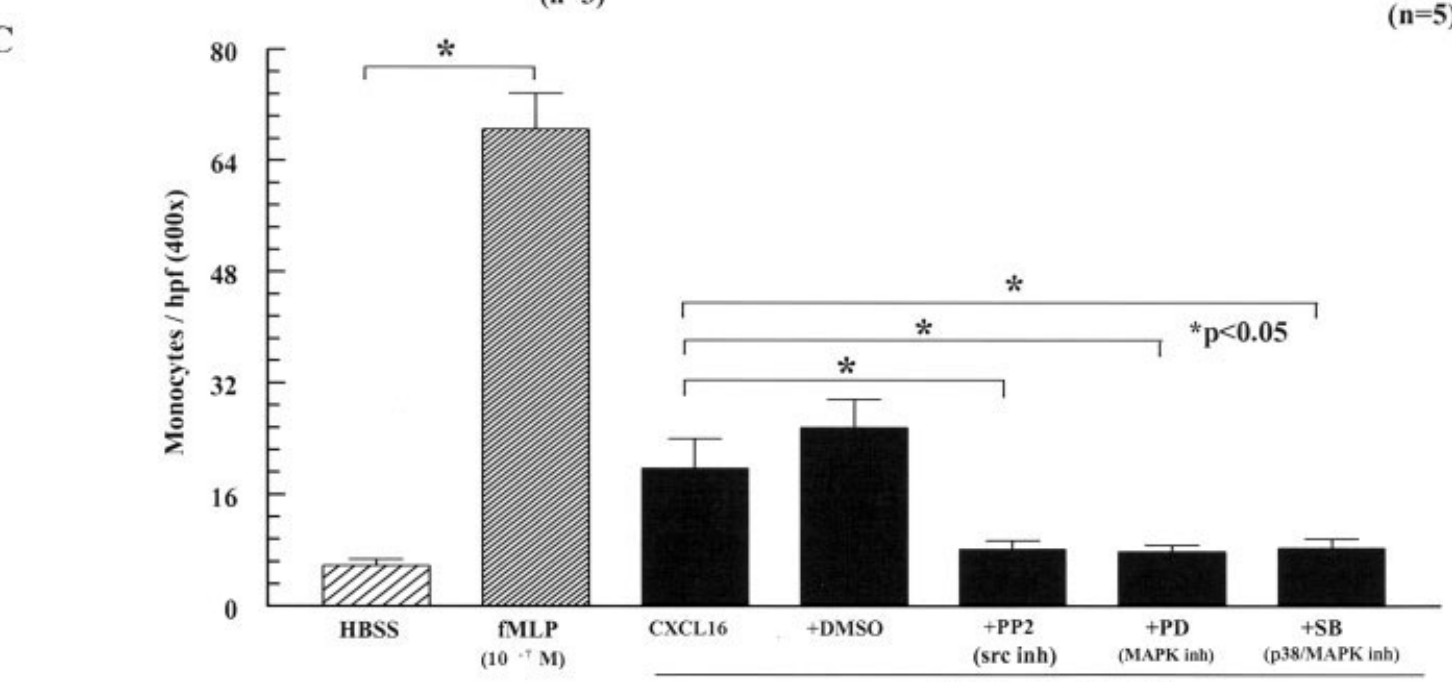

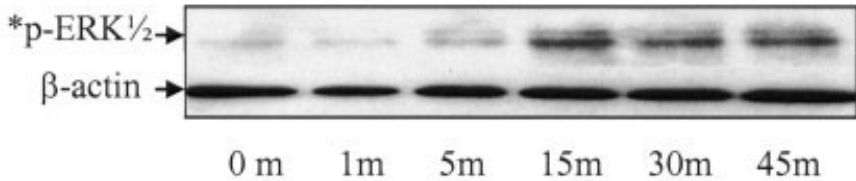

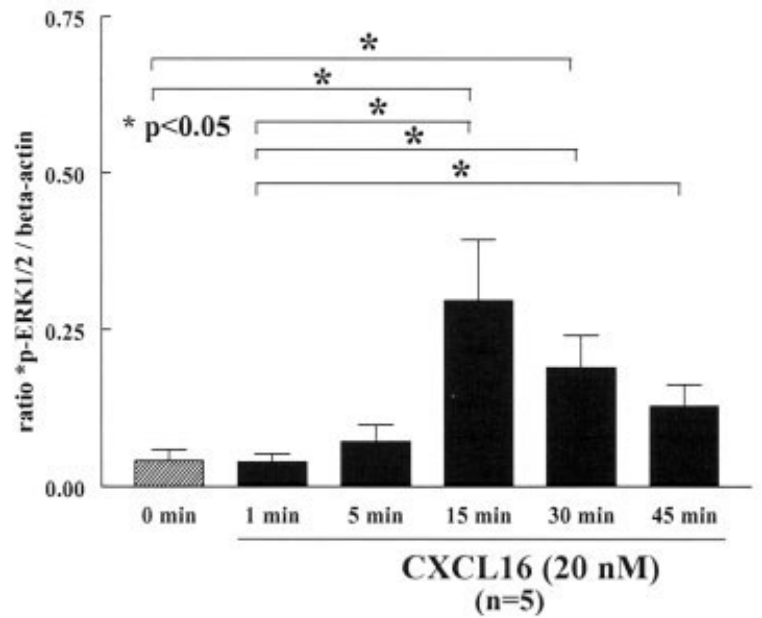

CXCL16 (20nM)

Figure 4. CXCL16 activates Raf and ERK-1/2 in a time-dependent manner. Monocytes $\left(2.5 \times 10^{6}\right)$ were stimulated with $20 \mathrm{n} M$ recombinant human CXCL16. Cell lysates were probed for p-Raf and p-ERK-1/2 by Western blotting, showing a marked increase in phosphorylation after 5 and 15 minutes, respectively. A, Representative blots for both p-Raf and p-ERK-1/2. B, Graphs corresponding to blots in A. Values are the mean and SEM ( $\mathrm{n}=$ number of blood donors). C, Chemotaxis for human monocytes was also measured in the presence of signaling pathway inhibitors (inh). Values are the mean and SEM $(\mathrm{n}=4-7$ donors per group). hpf $=$ high-power field; HBSS $=$ Hanks' balanced salt solution; PP2 = a Src inhibitor; PD = PD98059 (a MAPK inhibitor); SB = SB203508 (a p38 MAPK inhibitor).

in RA ST compared with OA ST, and we observed elevated macrophage staining for CXCR6 in RA ST compared with both normal and OA ST. RA ST lining cells, containing macrophages and fibroblasts, expressed significantly more CXCL16 and CXCR6 than did normal or OA ST.
Induction of MNC migration by CXCL16. Normal human PBMCs were assayed for their chemotactic response to CXCL16 in a modified Boyden chamber to determine a proinflammatory role for CXCL16. HBSS and fMLP served as negative and positive controls, respectively. We found a dose-dependent migration of 
human MNCs to CXCL16, with a peak between $2 \mathrm{n} M$ $(20 \mathrm{ng} / \mathrm{ml})$ and $20 \mathrm{n} M(200 \mathrm{ng} / \mathrm{ml})$ (Figure 3A). These levels were consistent with those found in RA SF (mean \pm SEM $44.4 \pm 4.4 \mathrm{ng} / \mathrm{ml}$ ). To determine the participation of CXCL16 in MNC migration in RA, RA SF samples containing average levels of CXCL16 (45 $\mathrm{ng} / \mathrm{ml}$ ) were incubated with anti-human CXCL16 antibody. SF samples were then tested in an in vitro migration assay and compared with sham-depleted controls. RA SF samples showed a $28 \%$ decrease $(P<0.05)$ in MNC migratory activity after incubation with neutralizing antibody to CXCL16 (Figure 3B).

Activation of Raf and ERK-1/2 in monocytes by CXCL16. To determine the signaling pathways mediating CXCL16 function, isolated normal human monocytes were cultured overnight and stimulated with CXCL16 for various time periods. Cell lysates were prepared and probed with anti-phospho-ERK-1/2 and anti-phospho-Raf by Western blotting. The blots were stripped and reprobed with $\beta$-actin to confirm equal loading of the samples. Monocyte stimulation with CXCL16 induced a marked increase in an early phosphorylation of Raf at 5 minutes and of ERK-1/2 at 15 minutes (Figure 4A). The graphs of 3 experiments with Raf and 5 experiments with ERK-1/2 are also shown (Figure 4B). These results were consistent with MAPK signaling, since Raf is upstream of ERK-1/2, and they indicated that CXCL16 may induce some of its proinflammatory properties through this pathway.

To further analyze the relevance of the MAPK pathway for monocyte recruitment, migration assays were performed with $20 \mathrm{n} M$ CXCL16 in the presence of various signaling pathway inhibitors at a final concentration of $10 \mu M$ (40). As shown in Figure 4C, monocyte migration was significantly blocked by PP2 (an inhibitor of Src), by PD98059 (a MAPK inhibitor), and by SB203508 (a p38 MAPK inhibitor), suggesting participation of Src and MAPK pathways for monocyte chemotaxis toward CXCL16 in vitro.

Recruitment by CXCL16 of MNCs in vivo to engrafted human ST in a SCID mouse chimera. To test MNC migration in vivo, we used a human ST-SCID mouse chimera. After 4-6 weeks, animals engrafted with human RA ST were killed. Well-engrafted tissues with no signs of rejection were observed and were used at this time point (Figure 5A). To determine homing of normal human MNCs, freshly isolated cells were dye-tagged with $\mathrm{PKH} 26$, and $5 \times 10^{6}$ cells/100 $\mu \mathrm{l} /$ mouse were injected IV via the tail vein 48 hours before mice were killed. Cryosections $(10 \mu \mathrm{m})$ of the RA ST grafts were examined using a fluorescence microscope with a
A

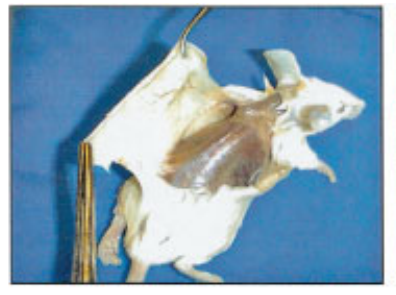

Side not grafted
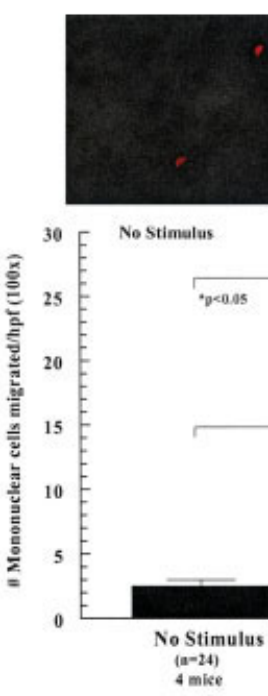

4 mice

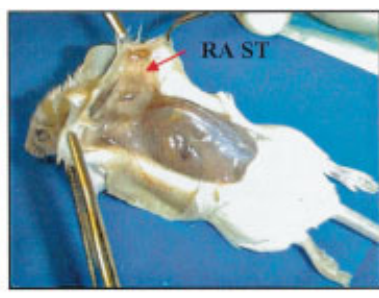

Side grafted with human RA ST
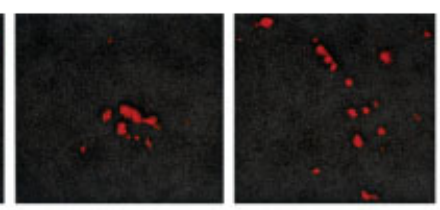

CXCL16
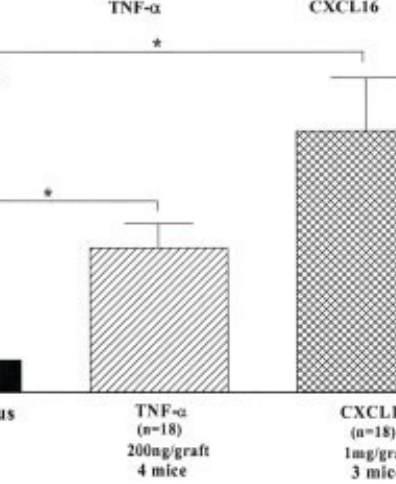

(n-18)
200ngigrat
4 mike
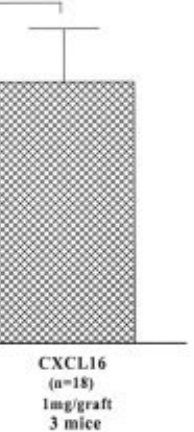

Figure 5. A, A SCID mouse grafted with RA ST. Left, An area where the RA ST graft was not inserted. Right, Side of the mouse where the RA ST graft was inserted, clearly showing a viable, growing RA ST graft (arrow). The photograph was taken 5 weeks after engraftment. B, PKH26 red fluorescent dye-tagged human PB mononuclear cells $(5 \times$ $10^{6}$ ) were injected intravenously into SCID mice engrafted for 6-8 weeks with human RA ST. Before administering cells, ST grafts were injected with TNF $\alpha$ (200 ng/graft) or CXCL16 (1,000 ng/graft) or were sham injected (no stimulus). After 48 hours, grafts were harvested and tissue sections were examined by immunofluorescence microscopy at $550 \mathrm{~nm}$. Top, PKH26 dye-tagged mononuclear cells (original magnification $\times 100$ ). Bottom, Numbers of dye-tagged cells migrating to engrafted RA ST in response to the various stimuli. Cell migration was quantified by dividing the number of cells per high-power field (hpf). Values are the mean and SEM ( $\mathrm{n}=$ number of tissue sections counted). See Figure 1 for other definitions. Color figure can be viewed in the online issue, which is available at http:/www.arthritisrheum.org.

550-nm filter. Injection of CXCL16 or TNF $\alpha$ (positive control) into the engrafted RA ST prior to adoptive cell transfer resulted in a significant increase of MNC migration (39) (Figure 5B). To ensure that cell recruitment was induced by CXCL16 and not by contaminants, only additive-free and sterile-filtered CXCL16 was used. In addition, the soluble CXCL16 used in all experiments contained $<0.1 \mathrm{ng} / \mu \mathrm{g}$ ( 1 endotoxin unit $/ \mu \mathrm{g}$ ) endotoxin. These results indicate that exogenously administered CXCL16 is chemotactic for human MNCs in vivo. 
A
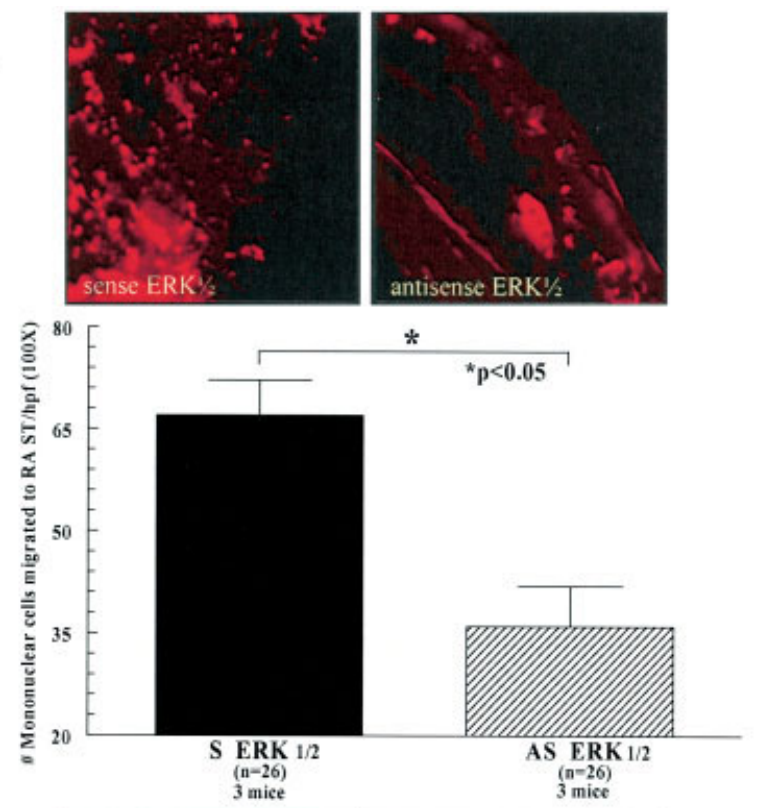

B

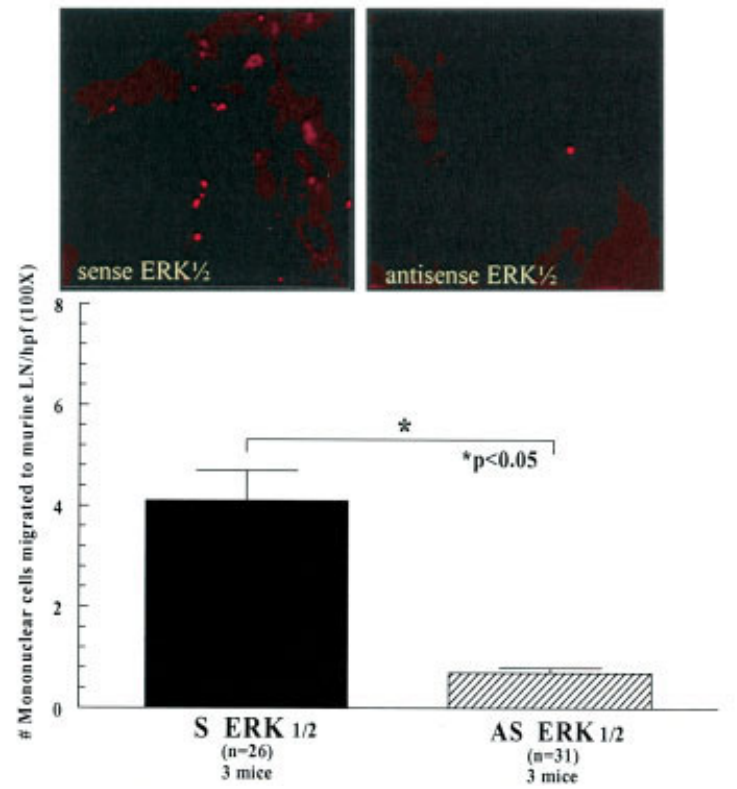

MNC chemotaxis to exogenously administered intragraft CXCL16 is reduced by 50\% to RA ST, and 5 -fold to murine LNs, in cells transfected with antisense ODNs for ERK-1/2. We further examined the participation of CXCL16 in the recruitment of MNCs in vivo by inhibiting the signaling pathways it utilizes. To do this, we transfected MNCs with sense or antisense ODNs for ERK-1/2, and then we labeled the transfected cells with PKH26 fluorescent dye. Before dye-tagging the cells, we performed viability counts in order to make certain that
C

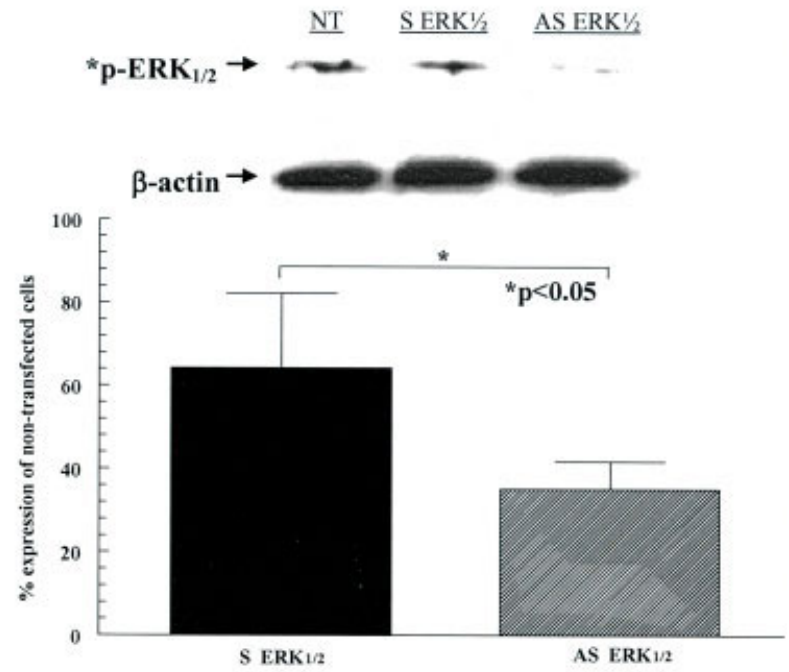

Figure 6. Intravenous administration of fluorescent dye-tagged human mononuclear cells to SCID mice engrafted with human RA ST. A, Fluorescent human mononuclear cells lipofected with sense (S) oligodeoxynucleotides (ODNs) to ERK-1/2 migrated readily to engrafted human RA ST in response to an intragraft injection of human CXCL16, whereas those cells lipofected with antisense (AS) ODNs to ERK-1/2 showed reduced migratory activity. B, Fluorescent human mononuclear cells lipofected with sense ODNs to ERK-1/2 migrated readily to murine lymph nodes (LNs) in response to an intragraft injection of human CXCL16, whereas those cells lipofected with antisense ODNs to ERK-1/2 showed reduced migratory activity. Values in $\mathbf{A}$ and $\mathbf{B}$ are the mean and SEM $(n=$ number of tissue sections counted from 3 mice per group). C, Mononuclear cells transfected with antisense ODNs to ERK-1/2, but not nontransfected (NT) or sense-transfected mononuclear cells, showed significant inhibition of p-ERK-1/2 expression. D, A significant percentage of mononuclear cell inhibition of ERK-1/2 expression using antisense ODNs to ERK-1/2 is shown compared with sense-transfected mononuclear cells. Values are the mean and SEM. The experiment was repeated 3 times. $\beta$-actin served as the loading control. hpf $=$ high-power field (see Figure 1 for other definitions). (Original magnification $\times 100$.) Color figure can be viewed in the online issue, which is available at http://www.arthritisrheum.org.

cells did not experience an increased rate of cell death. Transfected dye-tagged cells were injected into tail veins of SCID mice bearing RA ST receiving simultaneous intragraft injections of CXCL16. Engrafted RA ST and murine inguinal LNs were removed 48 hours later. Transfection with antisense ODNs resulted in significant reductions of MNC migration compared with sensetreated controls (Figures 6A and B). The attenuated migration to LNs was especially impressive considering the elevated mean \pm SEM concentrations of soluble 
human CXCL16 in the serum of mice receiving intragraft injections of CXCL16 (CXCL16-injected mice $1.91 \pm 0.23 \mathrm{ng} / \mathrm{ml}, \mathrm{n}=7$ mice; noninjected mice $0.84 \pm$ $0.21 \mathrm{ng} / \mathrm{ml}, \mathrm{n}=6$ mice $)(P<0.05)$ (data not shown).

To ensure that ERK-1/2 expression was inhibited by antisense ODNs, we performed Western blot analysis for ERK-1/2 expression in MNCs as described in Patients and Methods. As shown in Figure 6C, MNCs transfected with antisense ODNs to ERK-1/2, but not nontransfected or sense-transfected MNCs, showed significant inhibition of ERK-1/2 expression. These data, graphed in Figure 6D, show a significant percentage of MNC inhibition of ERK-1/2 expression using antisense ODNs to ERK-1/2 compared with sense-transfected MNCs. These results show that targeting CXCL16mediated signaling pathways influences MNC migration to RA ST and regional LNs in vivo.

\section{DISCUSSION}

Substantial progress in characterizing chemokines and chemokine receptor function in vitro has led to better understanding of cell migration $(3,5,11,32)$, but the limitations of the in vitro environment make it difficult to interpret how chemokines and corresponding receptors function in vivo. Limitations of in vitro migration assays include evaluating the role of a particular chemokine as it relates to other chemokines and chemokine receptors, and ranking the importance of chemokines and chemokine receptors in a particular disease. Indeed, many investigators have used a similar SCID mouse chimera to study the effects of gene therapy and RA ST fibroblast infiltration in vivo (41-43). Therefore, to evaluate the proinflammatory function of chemokines in RA, we developed an in vivo cell migration assay to determine the relative importance of chemokines and their respective cellular receptors in a human RA STSCID mouse chimera.

Manipulation of chemokines has shown promise for RA therapy. We previously showed that ENA-78, a CXC chemokine, is up-regulated in RA SF as well as in a rodent model of arthritis $(22,44)$. Immunodepletion of human ENA-78 resulted in decreased ability to chemoattract polymorphonuclear cells in vitro (22). Furthermore, anti-ENA-78 given systemically ameliorated signs and symptoms of rat AIA (44). Inhibition of CC chemokines also reduced joint inflammation. For example, in vivo inhibition of the CC chemokine MIP- $1 \alpha$ by IL-10 delayed the onset and reduced the severity of collagen-induced arthritis (CIA) in mice (45). A neutralizing antibody to MCP-1, another CC chemokine, sig- nificantly reduced ankle swelling in a rat model of RA (46). Chemokine antagonists have similarly shown promise. For instance, a 67-amino acid sequence of MCP-1 that specifically antagonizes MCP-1 abrogated arthritis in MRL-lpr autoimmune mice, and an antagonist of RANTES ameliorated CIA in mice (47-49). IL-1 receptor antagonist protein, a naturally produced specific antagonist of IL- $1 \beta$, has consistently shown potent antiinflammatory properties in animal models of inflammation (50-52) and is used in the treatment of RA (53-58). CXCL16 is a novel chemokine that has not been fully characterized in chronic disease, and it is especially of interest because its only known receptor to date has been shown to be highly expressed in chronic Th1 diseases such as RA (28).

Initial reports on CXCL16 in mice and humans showed predominant gene expression in spleen, LNs, and Peyer's patches, with little or no expression in other organs (24). Immunohistologic analysis revealed that macrophages in RA ST stained intensely for both CXCL16 and CXCR6. This staining is consistent with a recent report that CXCL16 is produced by macrophages (59). This was also confirmed by real-time RT-PCR analysis showing elevated CXCL16 mRNA in RA ST compared with OA and normal ST. CXCL16 was also strongly expressed on a subset of PB leukocytes, including CD14+ monocytes and macrophages, from which functional CXCL16 has been shown to be shed (25). These findings are completely consistent with FACS results indicating that $\sim 40 \%$ of CD14+ monocytes and $33 \%$ of memory CD4+ and CD8+ lymphocytes express CXCR6 in RA SF. The FACS results suggest that both monocytes and lymphocytes may use the CXCR6 receptor to migrate from the normal $\mathrm{PB}$ to the joints in response to CXCL16 expression.

In combination with expression of its receptor Bonzo/CXCR6 on T cell subsets, these results suggest a unique role for CXCL16 in chronic inflammation. Recent studies showing expression of both CXCL16 and its receptor on T lymphocytes, akin to IL-2 and its receptor, point to a possible mechanism of autocrine stimulation (60). Our LN data support this role for CXCL16 as a possible $\mathrm{T}$ lymphocyte regulatory factor. We observed elevated serum levels of CXCL16 when CXCL16 was injected intragraft into SCID mice (data not shown), explaining in part the impressive recruitment of MNCs to murine LNs.

RA patient data show that CXCL16 is highly expressed in RA SF, is a potent chemoattractant for MNCs in vitro, and is chemotactic for PBMCs to RA ST in vivo. These findings suggest that inhibition of CXCR6 
expression or CXCL16 signaling pathways may substantially halt migration of inflammatory cells to RA ST. Our hypothesis was formulated on the basis of strong preliminary data suggesting that CXCL16 is abundant in chronic inflammation and may be associated with type 1 inflammatory responses (28). We have reason to believe that although CXCL16 may play a dominant role in RA, it may very well be important in other chronic diseases such as OA, since we observed elevated mRNA expression of CXCL16 in OA compared with normal ST, and elevated soluble CXCL16 in OA SF compared with normal serum. Chandrasekar et al (61) demonstrated that CXCL16 signals via Gi, PI 3-kinase, Akt, I $\kappa$ B kinase, and NF- $\kappa \mathrm{B}$ in aortic smooth muscle cells, pointing to specific signaling pathways after CXCL16CXCR6 binding. We found that stimulation of monocytes with CXCL16 induced dose-dependent increases in phosphorylation of the signaling molecules Raf and ERK-1/2. This correlates with in vitro MNC migration assays. For example, in the presence of ERK-1/2 signaling pathway inhibitors, CXCL16-induced MNC migration was significantly blocked. Interestingly, FACS analysis showed that normal PB CD14+ monocytes had little or no expression of CXCR6.

These findings may indicate that other yetunknown receptors may also bind and respond to CXCL16. Indeed, our observation of robust in vitro recruitment of PB monocytes toward CXCL16 may be the result of monocytes using an alternative receptor for CXCL16. Also, it is possible that in the inflammatory milieu of the RA SF, SF monocytes predominantly use the CXCR6 receptor while inactivated PB monocytes use another receptor. Our data cannot completely rule out this possibility. We recently observed a similar phenomenon with MIP- $3 \alpha$, finding that PB monocytes do not express the only known receptor for MIP- $3 \alpha$, namely, CCR6, but that they readily migrate dose dependently toward MIP-3 $\alpha$ in vitro (5).

We tested the capacity of CXCL16 to recruit MNCs in vivo using the human RA ST-SCID mouse chimera. This model has been used successfully by other groups to show that engrafted RA ST not only keeps many of the morphologic and pathologic characteristics of RA ST (62), but also can be used as an appropriate model of RA (63). We found that tail vein-injected cells migrate to engrafted RA ST and murine LNs in response to intragraft injections of human CXCL16. We examined possible signaling mechanisms underlying this response. We found that preincubation of MNCs with antisense ODNs against ERK-1/2 resulted in a pronounced decline in cell recruitment to engrafted RA ST and inguinal LNs in CXCL16-injected SCID mice. Although other signaling pathways may certainly be involved, we report here that inhibition of a chemokineinduced signaling cascade can temper the inflammatory infiltrate in vivo.

These findings have twofold importance. First, we observed an increase in MNC migration in response to exogenously added chemokine. Second, the primary function of this chemokine could be reversed in vivo by inhibiting its signaling cascade. CXCL16 may have chemotactic potency apart from other chemokines shown to be expressed in RA $(1-3,5,6,14,16,21-23,44,64)$. This is supported by the finding that CXCL16 may function independently of TNF $\alpha$ and IL-1 $\beta$, at least in vitro. This was initially unexpected, considering the potent proinflammatory activity of these cytokines in RA (8). We found that cultured RA ST fibroblasts constitutively produce large amounts of CXCL16 $(\sim 1 \mathrm{ng} / \mathrm{ml})$, explaining in part the highly elevated levels of CXCL16 in RA SF. Previous reports show that TNF $\alpha$ further stimulates RA synovial fibroblasts to release a variety of chemokines, suggesting that cell recruitment is largely due to $\mathrm{TNF} \alpha$, and implicating $\mathrm{TNF} \alpha$ as an ultimate downstream eliciting agent $(3,5)$.

Interestingly, we found that incubation of RA ST fibroblasts with either TNF $\alpha$ or IL- $1 \beta$ failed to further increase CXCL16 expression, contrary to previous findings with fractalkine and MIP-3 $\alpha(3,5)$. This is especially important when considering the amounts of CXCL16 found in patient samples, reaching levels as high as 145 $\mathrm{ng} / \mathrm{ml}$ in some cases. It suggests that large amounts of CXCL16 may be produced in RA independently of established proinflammatory cytokines. This finding is consistent with results of a recent study showing that RA fibroblasts express CXCL16 directly when stimulated by way of the Toll-like receptor 2 ligand peptidoglycan (65).

In conclusion, we evaluated the expression and function of CXCL16 and its receptor CXCR6 in RA. We found both the ligand and receptor to be very highly expressed in RA, and we observed that CXCL16 functions to aggressively recruit MNCs in vivo via the Raf and ERK-1/2 kinase pathways. These results point to CXCL16 as a novel, potent MNC recruiter in RA inflammation.

\section{ACKNOWLEDGMENTS}

The authors would like to thank Dr. Steven M. Wolinsky for advice on this project. His thoughtful comments helped to make these studies possible. The authors would also like to thank Drs. Anthony J. Coyle and James B. Rottman of 
Millennium Pharmaceuticals for supplying the mouse antihuman CXCR6 IgG antibody used in the FACS studies.

\section{REFERENCES}

1. Koch AE, Kunkel SL, Harlow LA, Johnson B, Evanoff HL, Haines GK, et al. Enhanced production of monocyte chemoattractant protein-1 in rheumatoid arthritis. J Clin Invest 1992;90:772-9.

2. Koch AE, Kunkel SL, Harlow LA, Mazarakis DD, Haines GK, Burdick MD, et al. Macrophage inflammatory protein- $1 \alpha$ : a novel chemotactic cytokine for macrophages in rheumatoid arthritis. J Clin Invest 1994;93:921-8.

3. Ruth JH, Volin MV, Haines GK III, Woodruff DC, Katschke KJ Jr, Woods JM, et al. Fractalkine, a novel chemokine in rheumatoid arthritis and in rat adjuvant-induced arthritis. Arthritis Rheum 2001;44:1568-81.

4. Volin MV, Woods JM, Amin MA, Connors MA, Harlow LA, Koch AE. Fractalkine: a novel angiogenic chemokine in rheumatoid arthritis. Am J Pathol 2001;159:1521-30.

5. Ruth JH, Shahrara S, Park CC, Morel JC, Kumar P, Qin S, et al. Role of macrophage inflammatory protein- $3 \alpha$ and its ligand CCR6 in rheumatoid arthritis. Lab Invest 2003;83:579-88.

6. Szekanecz Z, Strieter RM, Kunkel SL, Koch AE. Chemokines in rheumatoid arthritis. Springer Semin Immunopathol 1998;20: $115-32$.

7. Szekanecz Z, Koch AE. Chemokines and angiogenesis. Curr Opin Rheumatol 2001;13:202-8.

8. Szekanecz Z, Koch AE, Kunkel SL, Strieter RM. Cytokines in rheumatoid arthritis: potential targets for pharmacological intervention. Drugs Aging 1998;12:377-90.

9. Alkhatib G, Combadiere C, Broder CC, Feng Y, Kennedy PE, Murphy PM, et al. CC CKR5: a RANTES, MIP- $1 \alpha$, MIP- $1 \beta$ receptor as a fusion cofactor for macrophage-tropic HIV-1. Science 1996;272:1955-8.

10. Ruth JH, Lukacs NW, Warmington KS, Polak TJ, Burdick M, Kunkel SL, et al. Expression and participation of eotaxin during mycobacterial (type 1) and schistosomal (type 2) antigen-elicited granuloma formation. J Immunol 1998;161:4276-82.

11. Katschke KJ Jr, Rottman JB, Ruth JH, Qin S, Wu L, LaRosa G, et al. Differential expression of chemokine receptors on peripheral blood, synovial fluid, and synovial tissue monocytes/macrophages in rheumatoid arthritis. Arthritis Rheum 2001;44:1022-32.

12. Murdoch C, Finn A. Chemokine receptors and their role in inflammation and infectious diseases. Blood 2000;95:3032-43.

13. Heydtmann M, Adams DH. Understanding selective trafficking of lymphocyte subsets. Gut 2002;50:150-2.

14. Koch AE, Kunkel SL, Burrows JC, Evanoff HL, Haines GK, Pope RM, et al. Synovial tissue macrophage as a source of the chemotactic cytokine IL-8. J Immunol 1991;147:2187-95.

15. Koch AE, Harlow LA, Haines GK, Amento EP, Unemori EN, Wong WL, et al. Vascular endothelial growth factor: a cytokine modulating endothelial function in rheumatoid arthritis. J Immunol 1994;152:4149-56.

16. Koch AE, Kunkel SL, Shah MR, Hosaka S, Halloran MM, Haines GK, et al. Growth-related gene product $\alpha$ : a chemotactic cytokine for neutrophils in rheumatoid arthritis. J Immunol 1995;155; 3660-6.

17. Koch AE, Halloran MM, Haskell CJ, Shah MR, Polverini PJ. Angiogenesis mediated by soluble forms of E-selectin and vascular cell adhesion molecule-1. Nature 1995;376:517-9.

18. Loetscher P, Dewald B, Baggiolini M, Seitz M. Monocyte chemoattractant protein 1 and interleukin 8 production by rheumatoid synoviocytes: effects of anti-rheumatic drugs. Cytokine 1994; 6:162-70.

19. Qin S, Rottman JB, Myers P, Kassam N, Weinblatt M, Loetscher $\mathrm{M}$, et al. The chemokine receptors CXCR3 and CCR5 mark subsets of $\mathrm{T}$ cells associated with certain inflammatory reactions. J Clin Invest 1998;101:746-54.

20. Loetscher P, Uguccioni M, Bordoli L, Baggiolini M, Moser B, Chizzolini C, et al. CCR5 is characteristic of Th1 lymphocytes. Nature 1998;391:344-5.

21. Volin MV, Shah MR, Tokuhira M, Haines GK, Woods JM, Koch AE. RANTES expression and contribution to monocyte chemotaxis in arthritis. Clin Immunol Immunopathol 1998;89:44-53.

22. Koch AE, Kunkel SL, Harlow LA, Mazarakis DD, Haines GK, Burdick MD, et al. Epithelial neutrophil activating peptide-78: a novel chemotactic cytokine for neutrophils in arthritis. J Clin Invest 1994;94:1012-8.

23. Koch AE, Polverini PJ, Kunkel SL, Harlow LA, DiPietro LA, Elner VM, et al. Interleukin-8 as a macrophage-derived mediator of angiogenesis. Science 1992;258:1798-801.

24. Matloubian M, David A, Engel S, Ryan JE, Cyster JG. A transmembrane CXC chemokine is a ligand for HIV-coreceptor bonzo. Nat Immunol 2000;1:298-304.

25. Wilbanks A, Zondlo SC, Murphy K, Mak S, Soler D, Langdon P, et al. Expression cloning of the STRL33/BONZO/TYMSTRligand reveals elements of $\mathrm{CC}, \mathrm{CXC}$, and $\mathrm{CX} 3 \mathrm{C}$ chemokines. J Immunol 2001;166:5145-54.

26. Nakayama T, Hieshima K, Izawa D, Tatsumi Y, Kanamaru A, Yoshie O. Cutting edge: profile of chemokine receptor expression on human plasma cells accounts for their efficient recruitment to target tissues. J Immunol 2003;170:1136-40.

27. Kim CH, Johnston B, Butcher EC. Trafficking machinery of NKT cells: shared and differential chemokine receptor expression among $\mathrm{V} \alpha 24(+) \mathrm{V} \beta 11(+)$ NKT cell subsets with distinct cytokine-producing capacity. Blood 2002;100:11-6.

28. Kim CH, Kunkel EJ, Boisvert J, Johnston B, Campbell JJ, Genovese MC, et al. Bonzo/CXCR6 expression defines type 1-polarized T-cell subsets with extralymphoid tissue homing potential. J Clin Invest 2001;107:595-601.

29. Kim CH, Rott L, Kunkel EJ, Genovese MC, Andrew DP, Wu L, et al. Rules of chemokine receptor association with $\mathrm{T}$ cell polarization in vivo. J Clin Invest 2001;108:1331-9.

30. Unutmaz D, Xiang W, Sunshine MJ, Campbell J, Butcher E, Littman DR. The primate lentiviral receptor Bonzo/STRL33 is coordinately regulated with CCR5 and its expression pattern is conserved between human and mouse. J Immunol 2000;165: 3284-92.

31. Arnett FC, Edworthy SM, Bloch DA, McShane DJ, Fries JF, Cooper NS, et al. The American Rheumatism Association 1987 revised criteria for the classification of rheumatoid arthritis. Arthritis Rheum 1988;31:315-24.

32. Ruth JH, Rottman JB, Katschke KJ Jr, Qin S, Wu L, LaRosa G, et al. Selective lymphocyte chemokine receptor expression in the rheumatoid joint. Arthritis Rheum 2001;44:2750-60.

33. Volin MV, Szekanecz Z, Halloran MM, Woods JM, Magua J, Damergis JA Jr, et al. PECAM-1 and leukosialin (CD43) expression correlate with heightened inflammation in rat adjuvantinduced arthritis. Exp Mol Pathol 1999;66:211-9.

34. Chomczynski P, Sacchi N. Single-step method of RNA isolation by acid guanidinium thiocyanate-phenol-chloroform extraction. Anal Biochem 1987;162:156-9.

35. Endesfelder S, Krahn A, Kreuzer KA, Lass U, Schmidt CA, Jahrmarkt C, et al. Elevated p21 mRNA level in skeletal muscle of DMD patients and $\mathrm{mdx}$ mice indicates either an exhausted satellite cell pool or a higher p21 expression in dystrophin-deficient cells per se. J Mol Med 2000;78:569-74.

36. Favy DA, Lafarge S, Rio P, Vissac C, Bignon YJ, Bernard-Gallon D. Real-time PCR quantification of full-length and exon 11 spliced BRCA1 transcripts in human breast cancer cell lines. Biochem Biophys Res Commun 2000;274:73-8.

37. Kumar P, Amin MA, Harlow LA, Polverini PJ, Koch AE. Src and 
phosphatidylinositol 3-kinase mediate soluble E-selectin-induced angiogenesis. Blood 2003;101:3960-8.

38. Zhu K, Amin MA, Kim MJ, Katschke KJ Jr, Park CC, Koch AE. A novel function for a glucose analog of blood group $\mathrm{H}$ antigen as a mediator of leukocyte-endothelial adhesion via intracellular adhesion molecule 1. J Biol Chem 2003;278:21869-77.

39. Blades MC, Ingegnoli F, Wheller SK, Manzo A, Wahid S, Panayi GS, et al. Stromal cell-derived factor 1 (CXCL12) induces monocyte migration into human synovium transplanted onto SCID mice. Arthritis Rheum 2002;46:824-36.

40. Morel JC, Park CC, Zhu K, Kumar P, Ruth JH, Koch AE. Signal transduction pathways involved in rheumatoid arthritis synovial fibroblast interleukin-18-induced vascular cell adhesion molecule-1 expression. J Biol Chem 2002;277:34679-91.

41. Jungel A, Distler JH, Kurowska-Stolarska M, Seemayer CA, Seibl R, Forster A, et al. Expression of interleukin-21 receptor, but not interleukin-21, in synovial fibroblasts and synovial macrophages of patients with rheumatoid arthritis. Arthritis Rheum 2004;50: $1468-76$.

42. Muller-Ladner U, Gay S. The SCID mouse: a novel experimental model for gene therapy in human rheumatoid arthritis. Drugs Today (Barc) 1999;35:379-88.

43. Neidhart M, Seemayer CA, Hummel KM, Michel BA, Gay RE, Gay S. Functional characterization of adherent synovial fluid cells in rheumatoid arthritis: destructive potential in vitro and in vivo. Arthritis Rheum 2003;48:1873-80.

44. Halloran MM, Woods JM, Strieter RM, Szekanecz Z, Volin MV, Hosaka S, et al. The role of an epithelial neutrophil-activating peptide-78-like protein in rat adjuvant-induced arthritis. J Immunol 1999;162:7492-500.

45. Kasama T, Strieter RM, Lukacs NW, Lincoln PM, Burdick MD, Kunkel SL. Interleukin-10 expression and chemokine regulation during the evolution of murine type II collagen-induced arthritis. J Clin Invest 1995;95:2868-76.

46. Ogata H, Takeya M, Yoshimura T, Takagi K, Takahashi K. The role of monocyte chemoattractant protein-1 (MCP-1) in the pathogenesis of collagen-induced arthritis in rats. J Pathol 1997; 182:106-14.

47. Gong JH, Ratkay LG, Waterfield JD, Clark-Lewis I. An antagonist of monocyte chemoattractant protein 1 (MCP-1) inhibits arthritis in the MRL-lpr mouse model. J Exp Med 1997;186:131-7.

48. Wooley PH, Schaefer C, Whalen JD, Dutcher JA, Counts DF. A peptide sequence from platelet factor 4 (CT-112) is effective in the treatment of type II collagen induced arthritis in mice. J Rheumatol 1997;24:890-8.

49. Plater-Zyberk C, Hoogewerf AJ, Proudfoot AE, Power CA, Wells TN. Effect of a CC chemokine receptor antagonist on collagen induced arthritis in DBA/1 mice. Immunol Lett 1997;57:117-20.

50. Ruth JH, Bienkowski M, Warmington KS, Lincoln PM, Kunkel SL, Chensue SW. IL-1 receptor antagonist (IL-1ra) expression, function, and cytokine-mediated regulation during mycobacterial and schistosomal antigen-elicited granuloma formation. J Immunol 1996;156:2503-9.

51. Gabay C, Marinova-Mutafchieva L, Williams RO, Gigley JP,
Butler DM, Feldmann M, et al. Increased production of intracellular interleukin-1 receptor antagonist type $\mathrm{I}$ in the synovium of mice with collagen-induced arthritis: a possible role in the resolution of arthritis. Arthritis Rheum 2001;44:451-62.

52. Palmer G, Talabot-Ayer D, Szalay-Quinodoz L, Maret M, Arend WP, Gabay C. Mice transgenic for intracellular interleukin-1 receptor antagonist type 1 are protected from collagen-induced arthritis. Eur J Immunol 2003;33:434-40.

53. Arend WP. The balance between IL-1 and IL-1Ra in disease. Cytokine Growth Factor Rev 2002;13:323-40.

54. Arend WP, Malyak M, Guthridge CJ, Gabay C. Interleukin-1 receptor antagonist: role in biology. Annu Rev Immunol 1998;16: 27-55.

55. Firestein GS, Boyle DL, Yu C, Paine MM, Whisenand TD, Zvaifler NJ, et al. Synovial interleukin-1 receptor antagonist and interleukin-1 balance in rheumatoid arthritis. Arthritis Rheum 1994;37:644-52.

56. Fleishmann RM. Safety of anakinra, a recombinant interleukin-1 receptor antagonist (r-metHuIL-1ra), in patients with rheumatoid arthritis and comparison to anti-TNF $\alpha$ agents. Clin Exp Rheumatol 2002;20 Suppl 27:S35-41.

57. Kay J, Calabrese L. The role of interleukin-1 in the pathogenesis of rheumatoid arthritis. Rheumatology (Oxford) 2004;43 Suppl 3:III2-9.

58. Olsen NJ, Stein CM. New drugs for rheumatoid arthritis. N Engl J Med 2004;350:2167-79.

59. Van der Voort R, van Lieshout AW, Toonen LW, Sloetjes AW, van den Berg WB, Figdor CG, et al. Elevated CXCL16 expression by synovial macrophages recruits memory $\mathrm{T}$ cells into rheumatoid joints. Arthritis Rheum 2005;52:1381-91.

60. Shashkin P, Simpson D, Mishin V, Chesnutt B, Ley K. Expression of CXCL16 in human T cells. Arterioscler Thromb Vasc Biol 2003;23:148-9.

61. Chandrasekar B, Bysani S, Mummidi S. CXCL16 signals via Gi, PI3 kinase, Akt, I $\kappa \mathrm{B}$ kinase and nuclear factor- $\kappa \mathrm{B}$, and induces cell-cell adhesion and aortic smooth muscle cell proliferation. J Biol Chem 2004;279:3188-96.

62. Davis LS, Sackler M, Brezinschek RI, Lightfoot E, Bailey JL, Oppenheimer-Marks $\mathrm{N}$, et al. Inflammation, immune reactivity, and angiogenesis in a severe combined immunodeficiency model of rheumatoid arthritis. Am J Pathol 2002;160:357-67.

63. Geiler T, Kriegsmann J, Keyszer GM, Gay RE, Gay S. A new model for rheumatoid arthritis generated by engraftment of rheumatoid synovial tissue and normal human cartilage into SCID mice. Arthritis Rheum 1994;37:1664-71.

64. Amin MA, Volpert OV, Woods JM, Kumar P, Harlow LA, Koch AE. Migration inhibitory factor mediates angiogenesis via mitogen-activated protein kinase and phosphatidylinositol kinase. Circ Res 2003;93:321-9.

65. Pierer M, Rethage J, Seibl R, Lauener R, Brentano F, Wagner U, et al. Chemokine secretion of rheumatoid arthritis synovial fibroblasts stimulated by Toll-like receptor 2 ligands. J Immunol 2004;172:1256-65. 